\title{
Expression of Grapevine leafroll-associated virus 3 Coat Protein Gene in Escherichia coli and Production of Polyclonal Antibodies
}

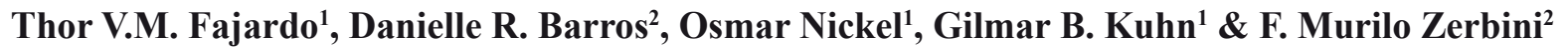 \\ 'Embrapa Uva e Vinho, Cx. Postal 130, CEP 95700-000, Bento Gonçalves, RS, Brasil, e-mail: thor@cnpuv.embrapa.br; \\ ${ }^{2}$ Departamento de Fitopatologia, BIOAGRO, Universidade Federal de Viçosa, CEP 36570-000, Viçosa, MG, Brasil, \\ e-mail: zerbini@ufv.br
}

Author for correspondence: Thor V.M. Fajardo

FAJARDO, T.V.M., BARROS, D.R., NICKEL, O., KUHN, G.B. \& ZERBINI, F.M. Expression of Grapevine leafroll-associated virus 3 coat protein gene in Escherichia coli and production of polyclonal antibodies. Fitopatologia Brasileira 32:496-500. 2007.

\begin{abstract}
Grapevine leafroll-associated virus 3 (GLRaV-3), the main viral species of the grapevine leafroll complex, causes yield and quality reduction in grapes (Vitis spp.). The coat protein gene was RT-PCR-amplified from total RNA extracted from infected grapevine leaves and the amplified fragment was cloned and completely sequenced. The fragment was subsequently subcloned into the pRSET-C expression vector. The recombinant plasmid was used to transform Escherichia coli BL21:DE3 and express the capsid protein. The coat protein, fused to a 6 His-tag, was purified by affinity chromatography using an Ni-NTA resin. The identity of the purified protein was confirmed by SDS-PAGE and Western blot. The in vitro-expressed protein was quantified and used for rabbit immunizations. The antiserum was shown to be sensitive and specific for the detection of GLRaV-3 in grapevine extracts in Western blot and DAS-ELISA assays, with no unspecific or heterologous reactions against other non-serologically related viruses being observed.

Additional keywords: grapevine, GLRaV-3, recombinant protein, serology, antibodies.

RESUMO

Expressão da proteína capsidial do Grapevine leafroll-associated virus 3 em Escherichia coli e produção de anticorpos policlonais

Grapevine leafroll-associated virus 3 (GLRaV-3), a principal espécie viral do complexo do enrolamento da folha da videira (Vitis spp.), causa reduções no rendimento e na qualidade da uva. O gene da proteína capsidial foi amplificado via RTPCR a partir de RNA total, extraído de folhas de videira infectadas. O fragmento amplificado foi clonado e completamente seqüenciado. Em seguida, o fragmento foi subclonado no vetor de expressão pRSET-C. O plasmídeo recombinante foi utilizado para a expressão da proteína capsidial em Escherichia coli BL21:DE3. A proteína capsidial, ligada a uma cauda de 6-His, foi purificada por cromatografia de afinidade em coluna de Ni-NTA. A identidade da proteína purificada foi confirmada em SDSPAGE e Western blot e, após quantificação, foi utilizada para imunizar coelhos. O anti-soro mostrou-se sensível e específico para a detecção do GLRaV-3 em extratos de videira por Western blot e DAS-ELISA, não tendo sido observadas reações inespecíficas ou heterólogas contra outros vírus sorologicamente não relacionados.
\end{abstract}

Palavras-chave adicionais: videira, GLRaV-3, proteína recombinante, sorologia, anticorpos.

Grapevine leafroll occurs in all main grapevine (Vitis spp.) growing regions worldwide, reducing the productivity and quality of grapes for consumption in natura and for processing, delaying ripening, negatively affecting the number, size and uniformity of bunches and the grape's pigmentation, as well as reducing sugar content. In Brazil, grapevine leafroll is a disease of economic relevance (Fajardo et al., 2003).

Nine serologically distinct viral species have been identified and associated with grapevines affected by leafroll, named Grapevine leafroll-associated virus, GLRaV-1 to -9. The disease is considered to be caused by a virus complex, although each viral species may occur individually in a plant. GLRaV-1, $-2,-3$ and -6 have already been detected in Brazil, with GLRaV-3 occuring most frequently (Martelli et al., 2002). GLRaV-3, the type-member of the genus
Ampelovirus (Closteroviridae), is the best characterized among the viruses of the grapevine leafroll virus complex. The coat protein (CP), encoded by ORF 6 (Ling et al., 1997; Martelli et al., 2002), has a predicted molecular mass of approximately $35 \mathrm{kDa}$ (Ling et al., 1997), estimated at 41.6 $\mathrm{kDa}$ (Rigotti et al., 2006) and $43 \mathrm{kDa}$ (Zimmermann et al., 1990) by SDS-PAGE and Western blot. According to Ling et al. (1997), the difference between the predicted molecular mass on the basis of the deduced amino acid sequence and estimated values from SDS-PAGE lies within acceptable range.

Generally, molecular methods such as RT-PCR are not suitable as routine tests for indexing large numbers of samples due to costs and the relative complexity of execution. On the other hand, indexing on woody indicators takes a long time for symptoms to be expressed (Nickel 
et al., 2004). As a consequence, serology has traditionally been the most used method of plant virus diagnosis in a large number of samples, using ELISA as the method of choice (Zimmermann et al., 1990; Ling et al., 2000).

Virus purification is usually a labor-intensive procedure with varying, occasionally unsatisfactory results concerning purity and concentration of the final preparation. Specifically for grapevine leafroll, the eight virus species associated with the disease are inseparable from the viral complex by biological means, with the exception of GLRaV2. Additionally, the lack of adequate herbaceous hosts, the low virus titer in woody plant tissues and the presence of inhibitor compounds such as polyphenols, tannins and polysaccharides are common difficulties that compromise purification of many plant viruses from their woody hosts (Ling et al., 2000; Ling et al., 2007). Also, antisera produced against different preparations of purified viruses may possess varying titers and specificities (Barbieri et al., 2004) which may lead to inconsistent diagnostic results.

With the development of molecular biology techniques, cloning and expressing of viral genes coding for structural (Ling et al., 2000; Minafra et al., 2000; Ling et al., 2007) and non-structural proteins has become an important strategy for obtaining large amounts of antigens with uniform concentration and stable properties among preparations (Targon et al., 1997; Barbieri et al., 2004; Nickel et al., 2004).

This study aimed to produce and characterize specific antibodies against the GLRaV-3-CP, expressing the coat protein in Escherichia coli. Where not stated otherwise, procedures were performed according to Sambrook \& Russel (2001). The coat protein (CP) gene of GLRaV-3, isolate Pet4, from grapevine cv. Petite Syrah collected in Petrolina, Pernambuco, Brazil, was amplified by RT-PCR with the oligonucleotides 8504 (5' ATGGCATTTGAACTGAAATT 3', viral sense) and 9445 (5' CTACTTCTTTTGCAATAGTT 3', complementary sense), ligated into the pGEM-T-Easy vector (Promega), cloned in E. coli DH5 $\alpha$ and completely sequenced (GenBank access number AY753208) (Fajardo et al., 2007). One recombinant clone containing the $\mathrm{CP}$ gene of GLRaV-3 (GLRaV-3cp, $942 \mathrm{bp}$ ) was cultured for $8 \mathrm{~h}$ at 37 ${ }^{\circ} \mathrm{C}$ in LB medium with $100 \mu \mathrm{g} / \mathrm{mL}$ ampicilin (LB/ampicilin), and the plasmid DNA was purified using the Flexi Prep kit (Amersham Biosciences), according to the manufacturer's instructions. The GLRaV-3cp gene was removed from the plasmid pGEM-T Easy by digestion with EcoRI and ligated to the expression vector pRSET-C (Invitrogen), previously digested with the same enzyme. For in vitro expression, the construct pRSET-C/GLRaV-3cp was transferred to $E$. coli strain BL21:DE3 by a heat shock procedure and one colony cultivated at $37^{\circ} \mathrm{C}$ in $200 \mathrm{~mL} \mathrm{LB} /$ ampicilin until an $\mathrm{OD}_{600}$ of approximately 0.5 , when expression was induced by addition of IPTG to a final concentration of $2 \mathrm{mM}$. Six hours post-induction, the bacterial cells were collected by centrifugation $(5,000 \mathrm{~g} / 10 \mathrm{~min})$ and stored at $-80^{\circ} \mathrm{C}$. Total protein extracts were obtained by re-suspension in lysis buffer (50 mM Tris- $\mathrm{HCl}, 100 \mathrm{mM} \mathrm{NaCl}, 2 \mathrm{mM}$ EDTA, $\mathrm{pH}$ 8.0), lysozyme treatment and sonication as described by Noueiry et al. (1994). The CP extract, re-suspended in $1 \mathrm{~mL}$ of $100 \mathrm{mM} \mathrm{NaHCO}, \mathrm{pH} 9.0$, plus $0.5 \%$ SDS (w/v) was purified by affinity cromatography in Ni-NTA columns (Qiagen), according to the manufacturer's instructions. GLRaV-3cp expression was evaluated by SDS-PAGE and Western blot, using commercial antibodies against the $\mathrm{CP}$ of GLRaV-3 (Agritest). Protein quantification was done with the Bradford reagent (Bio-Rad) according to the manufacturer's instructions.

After dialysis in $10 \mathrm{mM}$ phosphate buffer, $\mathrm{pH} 7.4$, plus $0.425 \% \mathrm{NaCl}(\mathrm{w} / \mathrm{v}), 218,220,298,464$ and $789 \mu \mathrm{g}$ of the in vitro-expressed protein were injected intramuscularly into the hind legs of each of two white New Zealand rabbits, approximately 35 days old, at weekly intervals. The first injection was done with complete Freund's adjuvant (1:1 $\mathrm{v} / \mathrm{v}$ ), and the four remaining injections with incomplete Freund's adjuvant $(1: 1 \mathrm{v} / \mathrm{v})$. Beginning one week after the last injection, seven weekly bleedings were carried out (25-30 mL/bleeding/animal). Blood samples were allowed to coagulate for $1 \mathrm{~h}$ at $37^{\circ} \mathrm{C}$ and $30 \mathrm{~min}$ at $4^{\circ} \mathrm{C}$, and then centrifuged at 3,000 $\mathrm{g} / 10 \mathrm{~min}$. The supernatant (antisera) was aliquoted and stored at $-20^{\circ} \mathrm{C}$.

Purification of the globuline fraction ( $\operatorname{IgG})$ from the antisera was carried out by ion exchange chromatography in a DEAE-Sephacel resin (Sigma) equilibrated with $25 \mathrm{mM}$ sodium acetate buffer $\mathrm{pH} 5.2$, diluting the antisera 1:10 (v/v) in distilled water. An equal volume of saturated ammonium sulphate was used to precipitate proteins, the suspension was centrifuged at $3,000 \mathrm{~g} / 10 \mathrm{~min}$, the pellet was re-suspended in $2 \mathrm{~mL}$ of half-strength PBS and dialysed for $12 \mathrm{~h}$ at $4^{\circ} \mathrm{C}$ in the same buffer. Quantified globuline fractions were stored at $-20^{\circ} \mathrm{C}$.

Conjugate was prepared by mixing alkaline phosphatase type VII-S (Sigma) sedimented by centrifugation at $8,000 \mathrm{~g}$ for $20 \mathrm{~min}$ with $\operatorname{IgG}(1: 2 \mathrm{v} / \mathrm{v})$. The mixture was dialysed in half-strength PBS for $12 \mathrm{~h}$. Glutaraldehyde was added at $0.06 \%(\mathrm{v} / \mathrm{v})$ and the mixture was incubated in the dark at $28^{\circ} \mathrm{C}$ for $4 \mathrm{~h}$ and dialysed again. Before the DASELISA procedures, PTA-ELISA (plate-trapped antigenELISA), using purified IgG from the produced GLRaV-3 antisera $(2 \mu \mathrm{g} / \mu \mathrm{L})$, was initially performed to evaluate the specific recognition with GLRaV-3-expressed CP (about 5 $\mu \mathrm{g} / \mu \mathrm{L})$ in this type of indirect ELISA test.

In preliminary assays to determine the antisera titer by DAS-ELISA (Clark \& Adams, 1977) using the purified CP $(1: 250$ and 1:500 v/v), IgG was evaluated at 1,2 and $4 \mu \mathrm{g} / \mathrm{mL}$ and the conjugate was diluted 1:200, $1: 400,1: 800,1: 1,000,1: 2,000$ and 1:4,000 (v/v) for each $\mathrm{IgG}$ concentration. Sensitivity and specificity of the collected antisera were evaluated by DAS-ELISA and by Western blot using healthy and GLRaV-3-infected grapevines maintained in greenhouses, which had been previously biologically indexed. The samples, consisting of leaf veins and petioles, were powdered in the presence of liquid nitrogen and 
diluted 1:3 (w/v) in $500 \mathrm{mM}$ Tris- $\mathrm{HCl}, \mathrm{pH} 8.2$, containing $0.8 \% \mathrm{NaCl}(\mathrm{w} / \mathrm{v}), 2 \%$ polyvinylpyrrolidone $40,000(\mathrm{w} / \mathrm{v})$, $1 \%$ polyetheleneglycol $6,000(\mathrm{w} / \mathrm{v})$ and $0.05 \%$ Tween 20 $(\mathrm{v} / \mathrm{v})$. Samples were considered infected when absorbance at $405 \mathrm{~nm}$ was at least twice the average value of the healthy controls.

Additionally, the DAS-ELISA assay was performed to confirm the GLRaV-3 antibody specificity and to demonstrate the lack of serological relationship between produced GLRaV-3 antisera and some antigens, including other grapevine virus [Grapevine leafroll-associated virus 1 (GLRaV-1), GLRaV-2, GLRaV-5, GLRaV-7, Grapevine fanleaf virus (GFLV), Grapevine fleck virus (GFkV), Grapevine virus A (GVA), Grapevine virus B (GVB)] and Apple chlorotic leaf spot virus (ACLSV).

Samples for Western blot were ground in TBS (20 $\mathrm{mM}$ tris, $500 \mathrm{mM} \mathrm{NaCl}$ ), pH 7.5 plus $0.2 \%$ sodium sulfite $(\mathrm{w} / \mathrm{v}), 1: 5(\mathrm{w} / \mathrm{v})$. For comparison, commercial antibodies against the GLRaV-3cp (Agritest) were used in both assay.

Expression of the GLRaV-3cp was induced three times in $200 \mathrm{~mL}$ cultures, thus obtaining 2.121, 1.966 and $1.578 \mathrm{mg}$ coat protein in each induction. Compared to other results (Targon et al., 1997; Ling et al., 2000; Ling et al., 2007) on fusion protein expression, the average protein yield obtained in this study $(10.6 \mu \mathrm{g} / \mathrm{mL}$ culture medium) was considered adequate for the required immunizations.

The expressed coat protein was analyzed by SDSPAGE in which the presence of a band with a molecular mass corresponding to approximately $44 \mathrm{kDa}$, an expected value for the fusion protein, was observed (Figure 1A); ca. $41 \mathrm{kDa}$ corresponding to the GLRaV-3cp itself, increased by approximately $3 \mathrm{kDa}$, of amino acids ligated to the $\mathrm{N}$ terminal of the GLRaV-3cp, including the 6-His tag. The band corresponding to the fusion protein was absent in the sample transformed with the empty vector (Figure 1A). The identity of the expressed protein was confirmed by Western blot (Figure 1B). One band migrating ahead of the fusion protein indicates a common post-purification degradation process (Figures 1A-B).

Testing the antisera for the specific detection of GLRaV-3 by Western blot revealed that it reacted strongly with extracts from virus-infected plants, demonstrating high sensitivity and specificity. The antisera did not show the least reaction to healthy samples (Figure 2). The purified IgG was obtained in a concentration of $1.278 \mu \mathrm{g} / \mathrm{mL}$, and its positive reactivity to GLRaV-3-expressed $\mathrm{CP}\left(\mathrm{A}_{405 \mathrm{~mm}}=1.82\right.$; healthy control $=0.14$ ) was also confirmed by PTA-ELISA.

In DAS-ELISA, the antiserum reacted with the in vitro-expressed $\mathrm{CP}$ as well as with leaf extracts from infected plants in dilutions of up to $1 \mu \mathrm{g} / \mathrm{mL}$ and $1: 4,000$ of $\mathrm{IgG}$ and conjugate, respectively (Table 1). The dilutions finally chosen for IgG and conjugate, $2 \mu \mathrm{g} / \mathrm{mL}$ and 1:1,000, respectively, gave the best and most reproducible reactions. Healthy grapevine absorbance values were compatible with sensitive and reliable GLRaV-3 detection. The antiserum did not show heterologous cross reactions with other non-

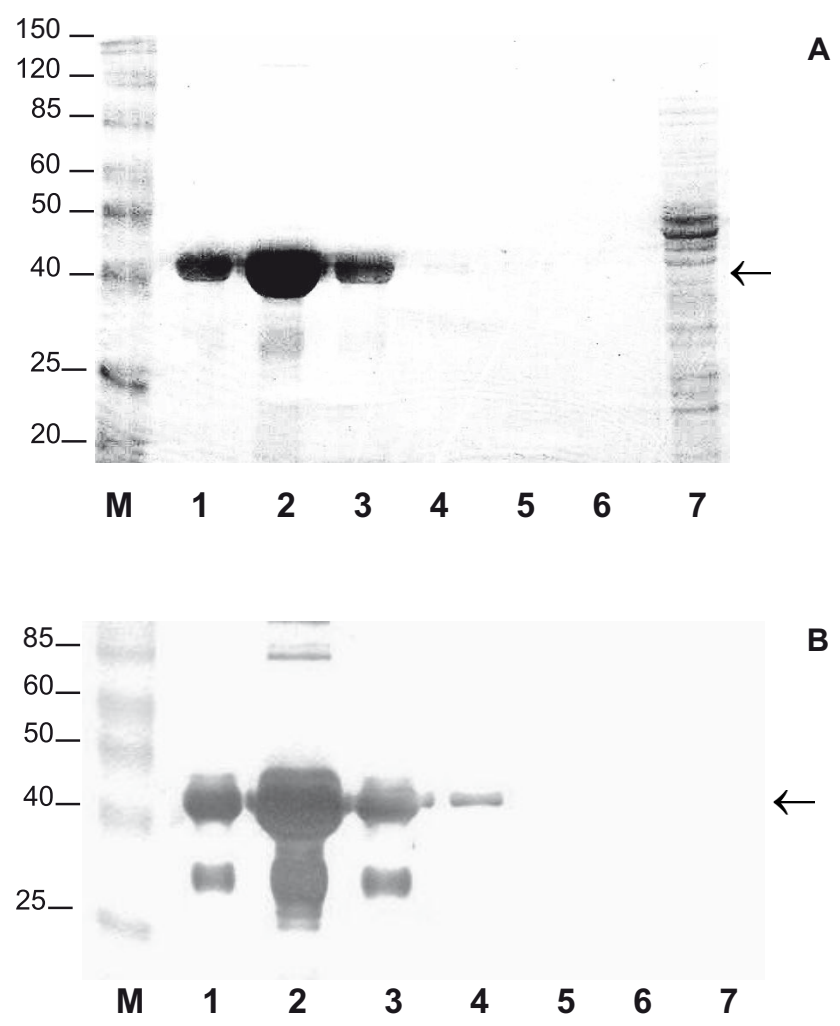

FIG. 1 - A. SDS-polyacrylamide gel electrophoresis, 12\%, stained with Coomassie Blue; B. Western blot with commercial antiserum (Agritest) against Grapevine leafroll-associated virus 3 (GLRaV3) $(1: 750 \mathrm{v} / \mathrm{v})$. Samples in both gels: Lanes 1 to 6 , aliquots $(5 \mu \mathrm{L})$ of sequential fractions of total protein extracts from Escherichia coli transformed with the construct pRSET-C/GLRaV-3cp, collected from Ni-NTA-column; Lane 7, aliquot $(5 \mu \mathrm{L})$ of the control extract containing the empty expression vector pRSET-C. M, molecular mass markers $(\mathrm{kDa})$. Arrows on the right indicate the position of the fusion protein.

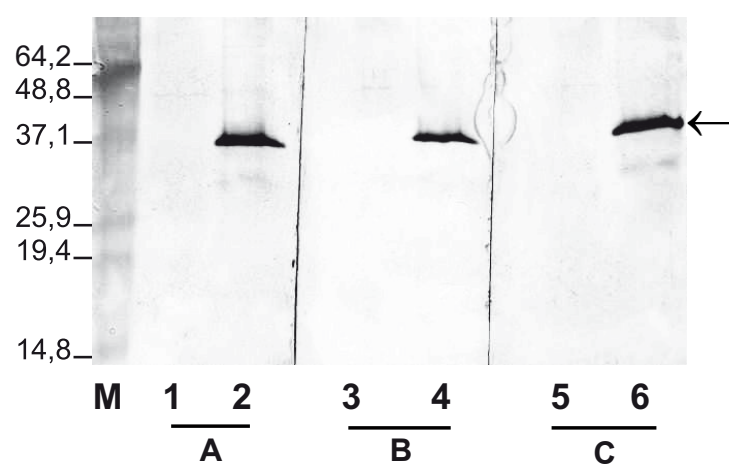

FIG. 2 - Western blot with antisera against the fusion protein obtained from $2^{\text {nd }}(A), 3^{\text {rd }}(B)$ and $4^{\text {th }}(C)$ bleedings $(1: 250 \mathrm{v} / \mathrm{v})$; Lanes $1,3,5$, extracts from healthy grapevine cv. Itália, 1:3 (w/v) $(20 \mu \mathrm{L})$; Lanes 2, 4, 6, extracts from GLRaV-3-infected grapevine cv. Petite Syrah, 1:3 (w/v) $(20 \mu \mathrm{L})$. M, molecular mass markers $(\mathrm{kDa})$. The arrow on the right indicates the GLRaV-3 coat protein position. 
Expression of Grapevine leafroll-associated virus 3 coat protein...

TABLE 1 - Results of DAS-ELISA (absorbance values at $405 \mathrm{~nm}$ ) from grapevine (Vitis spp.) samples using antiserum against GLRaV-3 fusion protein, expressed in Escherichia coli cells

\begin{tabular}{|c|c|c|c|c|c|}
\hline \multirow[t]{2}{*}{ Samples } & \multicolumn{5}{|c|}{$\begin{array}{c}\text { Absorbance at } 405 \mathrm{~nm} \\
\text { IgG }(\mu \mathrm{g} / \mathrm{mL}) / \text { Conjugate }(\mathrm{v} / \mathrm{v})\end{array}$} \\
\hline & $\begin{array}{c}4 / \\
1: 1000 \\
(30 \mathrm{~min})\end{array}$ & $\begin{array}{c}4 / \\
1: 2000 \\
(30 \mathrm{~min})\end{array}$ & $\begin{array}{c}2 / \\
1: 1000 \\
(50 \mathrm{~min})\end{array}$ & $\begin{array}{c}4 / \\
1: 2000 \\
(50 \mathrm{~min})\end{array}$ & $\begin{array}{c}2 / \\
1: 500 \\
\text { (40 min) }\end{array}$ \\
\hline $\begin{array}{l}\text { Healthy grapevine (cv. Itália } 1: 3 \mathrm{w} / \mathrm{v} \\
\text { or Agritest extract) }\end{array}$ & 0.30 & 0.15 & 0.30 & 0.25 & 0.30 \\
\hline GLRaV -3-infected grapevine cv. Petite Syrah 1:3 (w/v) & 0.90 & 0.51 & 0.83 & 0.75 & n.d. \\
\hline Expressed GL RaV -3cp fusion protein 1:500 (v/v) & 3.22 & 1.81 & $>3.50$ & 2.93 & n.d. \\
\hline Grapevine leafroll-associated virus 1 (Agritest grapevine extract) & n.d. & n.d. & n.d. & n.d. & 0.30 \\
\hline $\begin{array}{l}\text { Grapevine leafroll-associated virus } 2 \text { (Plantest-Sanofi grapevine } \\
\text { extract) }\end{array}$ & n.d. & n.d. & n.d. & n.d. & 0.19 \\
\hline $\begin{array}{l}\text { Grapevine leafroll-associated virus } 5 \text { (Plantest-Sanofi grapevine } \\
\text { extract) }\end{array}$ & n.d. & n.d. & n.d. & n.d. & 0.16 \\
\hline $\begin{array}{l}\text { Grapevine leafroll-associated virus } 7 \text { (Plantest-Sanofi grapevine } \\
\text { extract) }\end{array}$ & n.d. & n.d. & n.d. & n.d. & 0.18 \\
\hline Grapevine fanleaf virus (Agritest grapevine extract) & n.d. & n.d. & n.d. & n.d. & 0.26 \\
\hline Grapevine fleck virus (Agritest grapevine extract) & n.d. & n.d. & n.d. & n.d. & 0.24 \\
\hline Grapevine virus $A$-infected grapevine $(1: 3 \mathrm{w} / \mathrm{v})$ & n.d. & n.d. & n.d. & n.d. & 0.25 \\
\hline Grapevine virus $B$-infected grapevine $(1: 3 \mathrm{w} / \mathrm{v})$ & n.d. & n.d. & n.d. & n.d. & 0.18 \\
\hline Apple chlorotic leaf spot virus-infected apple (Malus spp.) $(1: 10 \mathrm{w} / \mathrm{v})$ & n.d. & n.d. & n.d. & n.d. & 0.26 \\
\hline
\end{tabular}

n.d., not determined

serologically related viruses (Table 1). Performance of the antiserum was similar to that obtained with commercial antibodies. Absorbance values from grapevine infected samples suggest that the virus titer was low in evaluated grapevine plants. In this work, DAS-ELISA was chosen to check the antiserum because of its low cost, reliability and practicality as a large-scale virus diagnostic method (Zimmermann et al., 1990; Ling et al., 2000).

Although a number of polyclonal antisera has been raised against recombinant viral proteins, only in a few cases were they effective in detecting the virus by ELISA, as previously reported by Ling et al. (2000) to GLRaV-3, using DAS-ELISA and by Ling et al. (2007) to GLRaV2, using PTA-ELISA. In this work, the complete GLRaV3 capsid protein gene was expressed, while the GLRaV-3 coat protein clone expressed by Ling et al. (2000) covered $96 \%$ of the coat protein gene, lacking 13 amino acid residues of the C-terminus. Antibodies raised against recombinant viral proteins are more frequently useful for virus detection through other means, including Western blot, immunoelectron microscopy (ISEM), immunocapture RT-PCR or indirect ELISA (Ling et al., 2007).

Antibodies produced against recombinant antigens may not be functional when used in non-denaturing procedures such as ELISA (Minafra et al., 2000), being more probably functional when used in denaturing assays such as Western blots (Nickel et al., 2004). Changes in the antigenic structure of the viral CP expressed in bacteria could be an explanation for the weak recognition of the native $\mathrm{CP}$ in infected plant samples (Minafra et al., 2000). In the present study the antibodies produced against the in vitro-expressed $\mathrm{CP}$ recognized the GLRaV-3cp sensitively and specifically in both systems.

The antibodies produced against the recombinant antigen GLRaV-3cp isolate Pet-4 were not tested against GLRaV-3 isolates Pet-1 to Pet-3, all collected in Northeastern Brazil, from which Pet-4 was shown to differ by only 11 amino acids (Fajardo et al., 2007). However, these antibodies were tested and recognized GLRaV-3 in other infected samples of different origins, such as distinct accessions of Cabernet Sauvignon $\left(\mathrm{A}_{405 \mathrm{~nm}}=1.02\right)$, Centennial (1.04), Chardonnay (1.07) and Clara (0.94) cultivars (healthy grapevine $\mathrm{A}_{405 \mathrm{~nm}}$ $=0.26$ ).

Barbieri et al. (2004) concluded, based on observations with Watermelon mosaic virus (WMV), family Potyviridae, genus Potyvirus, that antibodies produced against expressed CPs in E. coli tend to be more specific, reducing the occurrence of unexpected heterologous reactions. This property was shown in the results of Table 1 , as expected, the nine non-serologically GLRaV-3-related 
viruses (GLRaV-1, GLRaV-2, GLRaV-5, GLRaV-7, GFLV, GFkV, GVA, GVB and ACLSV) (Ling et al., 2007) did not react with the produced GLRaV-3 antisera.

Multiple infections in grapevines, found frequently under field conditions, make virus diagnosis based on symptoms difficult and misleading. Multiple grapevine virus infections also make conventional purification of Closteroviridae viruses for antisera production impracticable, especially when individual virus species diagnosis is required. The availability of antisera of high sensitivity and specificity, such as those obtained in this study from recombinant antigens, will allow reliable virus diagnosis in these woody hosts.

\section{ACKNOWLEDGEMENTS}

The authors would like to thank the Conselho Nacional de Desenvolvimento Científico e Tecnológico - CNPq for financial support (Proc. 470000/2005-8). Technical support by Marcos F. Vanni is gratefully acknowledged.

\section{REFERENCES}

BARBIERI, M.R., CARVALHO, M.G., ZAMBOLIM, E.M. \& ZERBINI, F.M. Expressão em Escherichia coli da proteína capsidial do Watermelon mosaic virus e produção de anti-soro. Fitopatologia Brasileira 29:215-219. 2004.

CLARK, M.F. \& ADAMS, A.N. Characteristics of the microplate method of enzyme linked immunosorbent assay for the detection of plant viruses. Journal of General Virology 34:475-483. 1977.

FAJARDO, T.V.M., KUHN, G.B. \& NICKEL, O. Doenças virais. In: Fajardo, T.V.M. (Ed.). Uva para processamento - Fitossanidade. Série Frutas do Brasil 35. Brasília DF. Embrapa Informação Tecnológica. 2003. pp. 45-62.

FAJARDO, T.V.M., DIANESE, E.C., EIRAS, M., CERQUEIRA, D.M., LOPES, D.B., FERREIRA, M.A.S.V. \& MARTINS, C.R.F. Variability of the coat protein gene of Grapevine leafroll-associated virus 3 in Brazil. Fitopatologia Brasileira 32:335-340. 2007.

LING, K.S., ZHU, H.Y., ALVIZO, H., HU, J.S., DRONG, R.F., SLIGHTOM, J.L. \& GONSALVES, D. The coat protein gene of grapevine leafroll associated closterovirus-3: cloning, nucleotide sequencing and expression in transgenic plants. Archives of
Virology 142:1101-1116. 1997.

LING, K.S., ZHU, H.Y., JIANG, Z.Y \& GONSALVES, D. Effective application of DAS-ELISA for detection of grapevine leafroll associated closterovirus-3 using a polyclonal antiserum developed from recombinant coat protein. European Journal of Plant Pathology 106:301-309. 2000.

LING, K.S., ZHU, H.Y., PETROVIC, N. \& GONSALVES, D. Serological detection of Grapevine leafroll virus 2 using an antiserum developed against the recombinant coat protein. Journal of Phytopathology 155:65-69. 2007.

MARTELLI, G.P., AGRANOVSKY, A.A., BAR-JOSEPH, M., BOSCIA, D., CANDRESSE, T., COUTTS, R.H.A., DOLJA, V.V., FALK, B.W., GONSALVES, D., JELKMANN, W., KARASEV, A.V., MINAFRA, A., NAMBA, S., VETTEN, H.J., WISLER, G.C. $\&$ YOSHIKAWA, N. The family Closteroviridae revised. Archives of Virology 147:2039-2044. 2002.

MINAFRA, A., CASATI, P., ELICIO, V., ROWHANI, A., SALDARELLI, P., SAVINO, V. \& MARTELLI, G.P. Serological detection of Grapevine rupestris stem pitting-associated virus (GRSPaV) by a polyclonal antiserum to recombinant virus coat protein. Vitis 39:115-118. 2000.

NICKEL, O., TARGON, M.L.N.P., FAJARDO, T.V.M., MACHADO, M.A. \& TRIVILIN, A.P. Polyclonal antibodies to the coat protein of Apple stem grooving virus expressed in Escherichia coli: production and use in immunodiagnosis. Fitopatologia Brasileira 29:558-562. 2004.

NOUEIRY, A.O., LUCAS, W.J. \& GILBERTSON, R.L. Two proteins of a plant DNA virus coordinate nuclear and plasmodesmal transport. Cell 76:925-932. 1994.

RIGOTTI, S., BITTERLIN, W. \& GUGERLI, P. Production of monoclonal antibodies to Grapevine leafroll-associated virus 7 (GLRaV-7). Extended Abstracts, $15^{\text {th }}$ Meeting of the International Council for the Study of Virus and Virus-like Diseases of the Grapevine, Stellenbosch, South Africa. 2006. pp. 200-202.

SAMBROOK, J. \& RUSSEL, D. Molecular Cloning: A Laboratory Manual. Third edition. New York NY. Cold Spring Harbor Laboratory Press. 2001.

TARGON, M.L.P.N., NIKOLAEVA, O., MANJUNATH, K.L., LEE, R.F., MULLER, G.W. \& MACHADO, M.A. Coat protein gene of a Brazilian isolate of the Citrus tristeza virus: cloning, expression in E. coli and production of polyclonal antiserum. Fitopatologia Brasileira 22:99-102. 1997.

ZIMMERMANN, D., BASS, P., LEGIN, R. \& WALTER, B. Characterization and serological detection of four closteroviruslike particles associated with leafroll disease on grapevine. Journal of Phytopathology 130:205-218. 1990. 